\title{
Formulated Feed for Strombus pugilis (Mollusca, Gastropoda) Allowed Effective Gonad Maturity
}

\author{
Fabiola Chong Sánchez, Martha Enríquez Díaz, Imelda Martínez Morales and Dalila Aldana Aranda*
}

Centro de Investigación y de Estudios Avanzados - Unidad Mérida, Laboratorio de Biología y Cultivo de Moluscos, Antigua Carretera a Progreso Km. 6, 97310 Mérida, Yucatan, Mexico

\begin{abstract}
Fighting conch Strombus pugilis is one of six Strombidae species distributed throughout the Caribbean. It is used as food, as an aquarium organism and its shell are popular in jewelry production. Conch aquaculture has been done traditionally by extracting egg masses from wild adults. This is an issue for several conch species protected by CITES. Intensive conch culture requires good growth rates and gonad maturity under laboratory conditions using formulated feed. An evaluation was done of the effect of inclusion of the red algae Halymenia and Spirulina on gonad maturity in S. pugilis using two experimental diets containing low and high concentrations of these algae $(2 \%$ and $8 \%$ of each). Each diet was fed to six groups of conch kept in $20 \mathrm{~L}$ aquaria at $27.5^{\circ} \mathrm{C}$. They were fed twice daily at $0.1 \mathrm{~g}$ feed/conch for 105 days. Gonad development and digestive gland structure were analyzed with histological techniques. Analysis of gonad development and vitellus granule diameter were analyzed for the two treatments and a control (wild conch). Wild conch females exhibited a reproductive cycle with $100 \%$ maturity at the beginning of this study, followed immediately by spawning (in two peaks: $50 \%$ and $34 \%$ ) and initiation of a new oogenesis cycle. Females fed the $8 \% \mathrm{H}$. floresii and $8 \%$ Spirulina diet exhibited two spawning peaks $(75 \%$ and $100 \%)$ spaced a month apart, and larger yolk granules than those in the control and the $2 \% \mathrm{H}$. floresii and $2 \%$ Spirulina diet. Proteoglycan granule abundance in the digestive cells did not differ between treatments. $H$. floressi and Spirulina may function as a feeding stimulant, enhancing feed intake and promoting gonadal maturity in $S$. pugilis broodstock under laboratory conditions
\end{abstract}

Keywords: Reproduction; Conch; Formulate diets; Algae; Aquaculture; Caribbean

\section{Introduction}

Fighting conch Strombus pugilis is one of six conch species distributed throughout the Caribbean Sea on sandy bottoms in inshore waters [1]. Along with the conches S. gigas and S. costatus, S. pugilis is a marine resource of ecological and economical importance [2]. Until recently, S. gigas meat was a popular staple food among human populations in the Caribbean region but is now used mostly as an ingredient in tourist restaurants. S. pugilis is still widely consumed by people in the Caribbean, and its shell is used in jewelry making. This conch species is also now sought after for use in aquariology, with prices ranging from $\$ 6$ to $\$ 30$ USD per animal in markets as varied as Southeast Florida, Brazil and the West Indies. Finally, conch species are grazers, and provide the important environmental service of keeping sea grass and algae in balance.

Extraction of wild conch has compromised some populations to the point that protective measures have been implemented. For example, queen conch S. gigas is considered to be commercially threatened in some Caribbean countries and is consequently protected by the Convention on International Trade in Endangered Species of Wild Fauna and Flora (CITES); indeed, in many countries a total ban is in place protecting organisms and egg masses. Culture of conch species is a promising alternative for producing animals for consumption and the aquarium trade, without harvesting wild individuals, thus ensuring the conservation of natural populations. Culture of $S$. gigas has been successful in terms of hatchery spat production, but still depends on wild egg masses, and spat growth still depends on the use of large areas of natural environment [3]. Dependence on wild egg masses is one of the main hindrances to completely autonomous conch culture. Two of the bottlenecks in intensive conch culture are lack of formulated feed adequate for producing a good growth rate, and attaining gonad maturity at an equal or greater rate than in wild populations. In a natural environment, conches feed on a complex diet of macroalgae, microbenthic organisms and biofilm ingested with sediment [4-6]. No data are available on the diet nutrient profile (i.e. energy level, protein and micronutrients) required by $S$. pugilis for proper gonad maturity [7], however, macroalgae is probably a primary component. The red algae Halymenia floressi is abundant in the waters of the Yucatan Peninsula, mainly on sublittoral rocky substrates [8]. The present study objective was to compare the progress of gonad maturity in adult $S$. pugilis between wild individuals and cultured individuals fed one of two isoprotein and isoenergetic diets enriched with different percentages of Halymenia floressi.

\section{Material and Methods}

\section{System and experimental animals}

Reproductive performance in adult $S$. pugilis was evaluated in an experimental aquaculture system at the Center for Research and Advanced Studies (Centro de Investigación y de Estudios Avanzados - CINVESTAV) in Merida, Yucatan, Mexico. The experimental system was composed of twelve $20 \mathrm{~L}$ glass aquaria $(40 \times 20 \times 25 \mathrm{~cm})$. Each aquaria contained filtered $(25 \mu \mathrm{m})$ sea water continuously oxygenated

*Corresponding author: Dalila Aldana Aranda, Centro de Investigación y de Estudios Avanzados-Unidad Mérida, Laboratorio de Biología y Cultivo de Moluscos, Antigua Carretera a Progreso Km. 6, 97310 Mérida, Yucatan, Mexico, Tel: 52 (999) 9429451; Fax: 52 (999) 9812334; E-mail: daldana@mda.cinvestav.mx

Received August 16, 2016; Accepted October 26, 2016; Published October 28 2016

Citation: Sánchez FC, Díaz ME, Morales IM, Aranda DA (2016) Formulated Feed for Strombus pugilis (Mollusca, Gastropoda) Allowed Effective Gonad Maturity. J Aquac Res Development 7: 453. doi: 10.4172/2155-9546.1000453

Copyright: (c) 2016 Sánchez FC, et al. This is an open-access article distributed under the terms of the Creative Commons Attribution License, which permits unrestricted use, distribution, and reproduction in any medium, provided the original author and source are credited. 
using an air pump, and kept at a temperature of $27.5^{\circ} \mathrm{C}$. Photoperiod was $12 \mathrm{~h}$ light $/ 12 \mathrm{~h}$ dark throughout the experimental period. Adult individuals were collected in the Ria Celestún Biosphere Reserve $\left(20^{\circ} 52^{\prime} 13.96^{\prime \prime} \mathrm{N} ; 90^{\circ} 24^{\prime} 00^{\prime \prime} \mathrm{W}\right)$. One hundred eight animals were randomly distributed at a density of nine per aquarium.

Two isoprotein and isocaloric diets were formulated with different proportions of algae: Diet 1 (D1) contained 8\% Spirulina and $8 \% H$. floressi; Diet 2 (D2) contained 2\% of each algae; and the control (WC) consisted of wild conch. Diets were tested simultaneously, with six replicates per diet. The animals were fed twice daily at a rate of $0.1 \mathrm{~g}$ per conch $^{-1}$ for 105 days. Uneaten feed was removed each day.

\section{Analytical methods}

Formulated diets were analyzed for crude protein content (total nitrogen $\times 6.25$ [9]), carbon and calories in triplicate using CN Flash EA (Thermo Quest Ltd. Milan, Italy). Crude lipid concentrations were determined by petroleum ether extraction using a micro Foss Soxtec Avanti 2050 Automatic System. Ash content was obtained by incinerating samples in a muffle at $600^{\circ} \mathrm{C}$ for $3 \mathrm{~h}$. Nitrogen-free extract with fiber was calculated by difference $[100 \%$ - (protein $\%+$ lipid $\%+$ ash \%)]. The same procedure was used to measure muscle nitrogen and carbon content in each treatment and the control at 5, 15, 30, 45, 60, 75,90 and 105 days.

\section{Histological analysis}

Histological analyses were done by first cutting the organ mass through the mid-section containing the digestive gland and gonad. Tissue samples were fixed in alcoholic Bouin fluid, and processed using standard histological techniques [10]. After dehydration in an ethanol series and clearing with Histosol Clearing Agent, the sections were embedded in Paraplast wax. Tissue sections $(6 \mu \mathrm{m}$ thick) were stained with a trichrome stain [10], which included Alcian blue (8GX Sigma-Aldrich) at $\mathrm{pH} 2.5$ to differentiate proteoglycans (blue granules). Gonad and digestive gland examination were done using a Leica DM2700 microscope. Images were taken with a Leica MC17 digital camera mounted to the microscope, and corrected for contrast and color (Adobe Photoshop CS6 software).

Effect of the diets on the analyzed individuals was determined based on histological features of gonadal maturity and digestive gland structure. Two microscope slides with five histological sections each were prepared for each individual. Gonad maturity stages were identified considering the amount of connective tissue between the ovigerous tubules, ovigerous tubule diameter, oocyte length and width, and yolk granule diameter. Testicular tissue maturity stage was based on the number of seminiferous tubules and their diameter. Yolk granule diameter was quantified for each oogenesis stage by measuring 100 yolk granules on three sections from three individuals (Toup View software by Toup Tek). Average values and standard deviations were calculated for each trait for each of the two treatments and wild conch (i.e. D1, D2 and WC). Glycoprotein granule frequency [11] was measured by counting the total number of granules observed in three fields of the five sections on each slide under 40x magnification and calculating the mean and standard deviation for each diet.

For each treatment and wild conch, the structure of digestive glands was evaluated using the feed index established by Aranda and Frenkiel [12]. Average values and standard deviations were calculated for each trait for each of the two treatments and the control (i.e. D1, D2 and WC).

\section{Statistical methods}

Significant differences $(\mathrm{P}<0.05)$ between diet feed index values per date were identified with a non-parametric Tukey test [13]. A one-way ANOVA [13] was applied to identify significant differences $(\mathrm{P}<0.05)$ between diets in yolk granule and ovocyte diameter; tubule diameter at various spermatogenesis stages; digestive cells; glycoprotein granules; and feed index per diet.

\section{Results}

\section{Diet composition}

Calorie content $\left(\mathrm{Kcal} \mathrm{kg}^{-1}\right)$ of formulated diets was 3943.5 in D1 and 3824.4 in D2, providing the same amount of energy (Table 1). Tissue wet weight and proximate biochemical composition for the two treatments (D1, D2) and wild conch (WC) were quantified. At the end of the experimental period, average tissue wet weight was $13.7 \pm 3.3$ for $\mathrm{D} 1,10.6 \pm 1.5$ for $\mathrm{D} 2$ and $17.9 \pm 3.6 \mathrm{~g}$ for WC. Initial organism protein content was $535 \mathrm{~g} \mathrm{Kg}^{-1}$, whereas final content was $541 \mathrm{~g} \mathrm{Kg}^{-1}$ for WC, $627 \mathrm{~g} \mathrm{Kg}^{-1}$ for D1 and $610 \mathrm{~g} \mathrm{Kg}^{-1}$ for and D2 (Table 2).

\section{Digestive glands}

Control (WC): In the wild conch, the digestive gland exhibited an array of adenomers (Figures 1A and 1B). All these secreting structures are connected to small ducts, which join larger ducts attached to the stomach. Two cell types make up the functional glandular structure: digestive and vacuolated. Digestive cells in the wild conch animals had an average length of $24.8 \pm 25.7 \mu \mathrm{m}$ and an average width of $8.3 \pm 2.0$ $\mu \mathrm{m}$; they contained large granules up to $6.2 \pm 1.7 \mu \mathrm{m}$ in diameter. These

\begin{tabular}{|c|c|c|}
\hline \multirow{2}{*}{ Ingredients $\left(\mathbf{g ~ K g}^{-1}\right)$} & \multicolumn{2}{|c|}{ Diets } \\
\hline & D1 & D2 \\
\hline Spirulina $s p ._{\mathrm{a}}$ & 80 & 20 \\
\hline Red algae (Halymenia floresii $)_{\mathrm{b}}$ & 80 & 20 \\
\hline Fish meal ${ }_{c}$ & 185 & 290 \\
\hline Soy flour & 230 & 210 \\
\hline Wheat flour & 120 & 80 \\
\hline Corn flour & 00 & 80 \\
\hline Corn starch & 269 & 264 \\
\hline Vitamins & 10 & 10 \\
\hline Minerals & 1.0 & 1.0 \\
\hline Carboxymethyl cellulose & 10 & 10 \\
\hline Fish oil & 05 & 05 \\
\hline Soy oil & 05 & 05 \\
\hline Soy lecithin & 05 & 05 \\
\hline \multicolumn{3}{|l|}{ Biochemical composition $\left(\mathrm{g} \mathrm{Kg}^{-1}\right)$} \\
\hline Proteins & 377 & 357 \\
\hline Lipids & 57 & 49 \\
\hline Nitrogen & 58 & 55 \\
\hline Carbon & 419 & 407 \\
\hline Gross Energy KJ Kg-1 & 16.51 & 16.11 \\
\hline Ash & 104.7 & 119.1 \\
\hline NFE & 461.3 & 474.9 \\
\hline \multicolumn{3}{|c|}{$\begin{array}{l}\text { aBiochemical composition of Spirulina: protein } 656 \mathrm{~g} \mathrm{~kg}^{-1} \text {; lipids } 59.1 \mathrm{~g} \mathrm{~kg}^{-1} \text {; } \\
\text { Carbon } 266 \mathrm{~g} \mathrm{~kg}^{-1} \text {; acquired from Grupo Nutrisa, S.A. de C.V. } \\
\text { 'Biochemical composition of Halymenia floresii: Protein } 305 \% \text {; lipid } 2.46 \% \text {; ash } \\
\text { 19.16\% [26]. } \\
\text { 'Biochemical composition of fish meal: protein } 650.8 \mathrm{~g} \mathrm{~kg}^{-1} \text {; lipids } 88.5 \mathrm{~g} \mathrm{~kg}^{-1} \text {; ash } \\
125 \mathrm{~g} \mathrm{~kg}^{-1} \text {; supplied by El Pedregal Silver Cup feed manufacturers. } \\
\text { NFE=Nitrogen free extract= } 100 \% \text { - (protein } \%+\text { lipid } \%+\text { ash } \% \text { ). }\end{array}$} \\
\hline
\end{tabular}

Table 1: Principal diet ingredients and biochemical composition of the experimenta diets 1 (D1) and 2 (D2) used to feed S.pugilis. 
Citation: Sánchez FC, Díaz ME, Morales IM, Aranda DA (2016) Formulated Feed for Strombus pugilis (Mollusca, Gastropoda) Allowed Effective Gonad Maturity. J Aquac Res Development 7: 453. doi: 10.4172/2155-9546.1000453

Page 3 of 8

\begin{tabular}{|c|c|c|c|c|c|c|c|c|c|c|c|c|c|c|c|}
\hline \multirow[b]{2}{*}{ Date } & \multicolumn{5}{|c|}{ WC } & \multicolumn{5}{|c|}{ D1 } & \multicolumn{5}{|c|}{ D2 } \\
\hline & $\begin{array}{l}\text { Tissues } \\
\text { wet weight } \\
\text { (g) }\end{array}$ & $\begin{array}{c}\text { Protein } \mathrm{g} \\
\mathrm{Kg}-1\end{array}$ & $\begin{array}{c}\text { Carbon } \mathrm{g} \\
\mathrm{Kg}^{-1}\end{array}$ & $\begin{array}{l}\text { Fibers } \\
\mathrm{g} \mathrm{Kg}^{-1}\end{array}$ & Kcal & $\begin{array}{c}\text { Tissues } \\
\text { wet weight } \\
\text { (g) }\end{array}$ & $\underset{\mathrm{Kg}^{-1}}{\text { Protein }} \mathrm{g}$ & $\begin{array}{l}\text { Carbon } \\
\mathrm{g} \mathrm{Kg}^{-1}\end{array}$ & $\begin{array}{l}\text { Fibers } \\
\mathrm{g} \mathrm{Kg}^{-1}\end{array}$ & Kcal & $\begin{array}{c}\text { Tissues wet } \\
\text { weight (g) }\end{array}$ & $\begin{array}{l}\text { Protein } \mathrm{g} \\
\mathrm{Kg}^{-1}\end{array}$ & $\begin{array}{l}\text { Carbon } \\
\mathrm{g} \mathrm{Kg}^{-1}\end{array}$ & $\begin{array}{l}\text { Fibers } \\
\mathrm{g} \mathrm{Kg}^{-1}\end{array}$ & Kcal \\
\hline 0 & $9.7 \pm 3.9$ & 535 & 330 & 130 & 3248 & $11.7 \pm 3.1$ & 535 & 330 & 130 & 3248 & $11.7 \pm 3.1$ & 535 & 330 & 130 & 3248 \\
\hline 15 & $8.6 \pm 3.4$ & 528 & 330 & 140 & 2759 & $11.6 \pm 1.5$ & 528 & 330 & 140 & 2759 & $11.6 \pm 1.5$ & 528 & 330 & 140 & 2759 \\
\hline 30 & $7.6 \pm 0.6$ & 542 & 330 & 130 & 3169 & $11.9 \pm 2.2$ & 623 & 340 & 37 & 3910 & $9.1 \pm 0.6$ & 60 & 330 & 68 & 3936 \\
\hline 45 & $10.5 \pm 3.8$ & 543 & 350 & 110 & 3382 & --- & 630 & 340 & 28 & 4029 & ---- & 60.3 & 330 & 66 & 4017 \\
\hline 60 & $10.8 \pm 2.3$ & 536 & 350 & 120 & 3165 & $10.7 \pm 1.4$ & 627 & 350 & 25 & 4138 & $9.2 \pm 1.4$ & 60.2 & 340 & 58 & 4214 \\
\hline 75 & $11.1 \pm 1.3$ & 532 & 340 & 130 & 3207 & $10.3 \pm 2.6$ & 628 & 340 & 29 & 4190 & $13.3 \pm 4.1$ & 61 & 330 & 62 & 4102 \\
\hline 90 & $13.1 \pm 2.9$ & 532 & 350 & 120 & 3430 & $11.5 \pm 1.5$ & 610 & 360 & 31 & 4205 & $12.8 \pm 2.5$ & 59.7 & 330 & 70 & 4177 \\
\hline 105 & $17.9 \pm 3.6$ & 541 & 340 & 120 & 3054 & $13.7 \pm 3.3$ & 627 & 350 & 25 & 4060 & $10.6 \pm 1.5$ & 61 & 320 & 68 & 4118 \\
\hline
\end{tabular}

$(---=$ No data available)

Table 2: Tissue wet weight and proximate composition (average and standard deviation; $\mathrm{n}=7$ ) of $S$. pugilis fed one of two formulated diets supplemented with $8 \% \mathrm{H}$. floresii (D1) or $2 \%$ H. floresii (D2) for 105 days, and a wild conch (WC) control treatment.

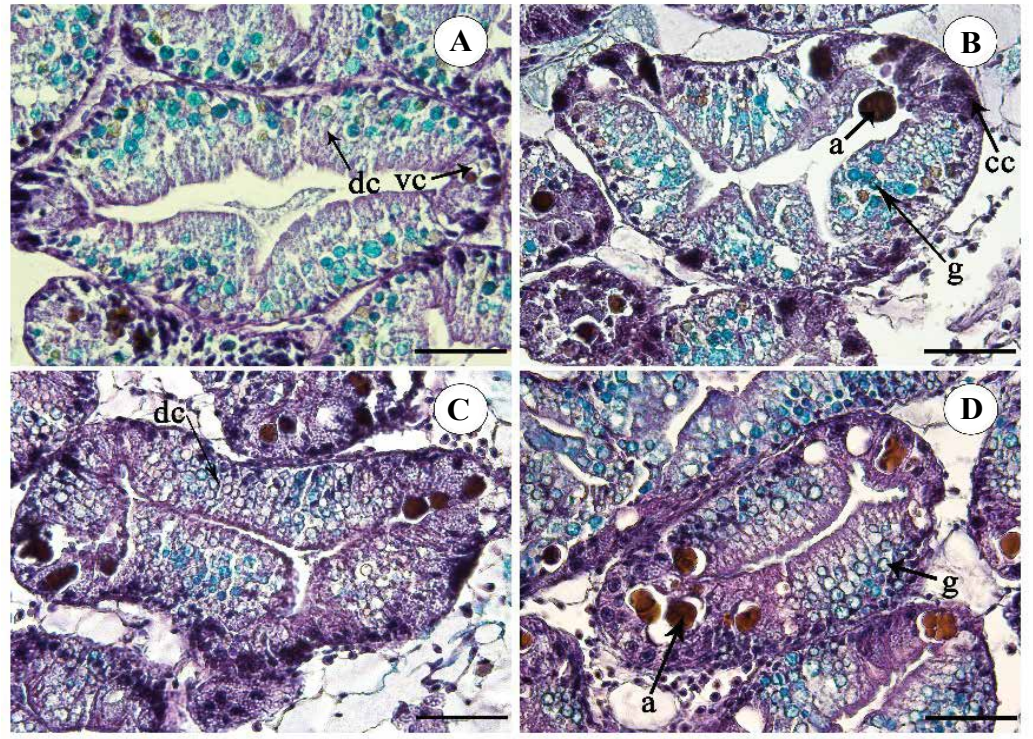

Figure 1: Initial and final condition of the digestive gland in wild conch Strombus pugilis (A and B), and final digestive gland condition in organisms fed Diet 1 (C) and Diet 2 (D) for 105 days. Images show the adenomeres (a); apicomplexa (ap); digestive cells (dg); cryptic cells (cc); and glycoprotein granules (gp). Magnification $40 x($ bar $=50 \mu \mathrm{m})$

cells alternated with vacuolated cells, which were always occupied by brown inclusions. These inclusions were sporozoa-like microorganisms belonging to the Apicomplexa group.

Laboratory-reared adults: In treatments D1 and D2, the digestive gland exhibited digestive cells like those in the wild conch, but with fewer and smaller blue granules (Figures $1 \mathrm{C}$ and $1 \mathrm{D}$ ). The sporozoalike microorganisms were also present. Blue granule diameters were 6.2 $\pm 1.7 \mu \mathrm{m}$ for WC, $5.6 \pm 1.5 \mu \mathrm{m}$ for D1 and $5.3 \pm 1.5 \mu \mathrm{m}$ for D2. Granule frequency was highest in the wild conch $(22.7 \pm 9.0)$, which was very similar to that of D2 $(21.2 \pm 9.8)$ (Table 3 and Figure 1$)$.

Average feed index in the wild conch treatment was $5.5 \pm 3.3$, with a maximum value of 11.2. In D1, the average feed index value was 3.2 \pm 1.8 and in D2 it was $3.5 \pm 1.6$ (Figure 2). The Kruskal-Wallis test identified significant differences $(\mathrm{P}<0.005)$ in median feed index values between treatments on days 45, 60 and 105 .

\section{Reproductive stages}

Reproductive stages did not vary between the control and the two treatments. The gonadal maturation process could be divided into four maturity stages, as described and characterized below (Figures $3 \mathrm{~A}-3 \mathrm{H}$ ).

\section{Females:}

(a) Early oogenesis: This stage exhibited initial yolk formation with extensive connective tissue between tubules. The ovigerous ducts measured $94.2 \pm 19 \mu \mathrm{m}$, smaller oocytes measured $41.9 \pm 13.2 \mu \mathrm{m}$ in length and $19.9 \pm 7.9 \mu \mathrm{m}$ width, and exhibited no yolk granules in the cytoplasm (previtellogenic oocytes). The nucleus had a very large nucleolus, with loose chromatin (Figure 3A and Table 4).

(b) Mid oogenesis: Connective tissue between the ovigerous tubules occurred in smaller amounts, and the ovigerous ducts were higher $(203.7 \pm 35.3 \mu \mathrm{m})$ than in early oogenesis. Some oocytes had a yolk while others did not. In large oocytes $(108.8 \pm 28.2 \mu \mathrm{m})$, yolk was present and the nucleolus was larger. Yolk granules measured $5.6 \pm 1.0$ $\mu \mathrm{m}$ (Figure 3B and Tables 4 and 5).

(c) End oogenesis (maturity): Connective tissue was almost nonexistent and ovigerous tubule walls were very thin. Most eggs were mature and completely occupied the tubule lumen. Eggs measured 213 
Citation: Sánchez FC, Díaz ME, Morales IM, Aranda DA (2016) Formulated Feed for Strombus pugilis (Mollusca, Gastropoda) Allowed Effective Gonad Maturity. J Aquac Res Development 7: 453. doi: 10.4172/2155-9546.1000453

Page 4 of 8

\begin{tabular}{c|c|c|c|c|}
\multirow{2}{*}{ Treatment } & \multicolumn{2}{|c}{ Digestive cells } & \multicolumn{2}{c}{ Blue granules } \\
\cline { 2 - 5 } & Length $(\boldsymbol{\mu m})$ & Width $(\boldsymbol{\mu m})$ & Counts $(\boldsymbol{\mu m})$ & Diameter $(\boldsymbol{\mu m})$ \\
\hline WC & $24.8 \pm 25.7^{\mathrm{b}}$ & $8.3 \pm 2.0^{\mathrm{b}}$ & $22.7 \pm 9.0^{\mathrm{b}}$ & $6.2 \pm 1.7^{\mathrm{c}}$ \\
\hline D1 & $36.7 \pm 21.2^{\mathrm{ab}}$ & $7.6 \pm 4.3^{\mathrm{ab}}$ & $17.2 \pm 8.6^{\mathrm{a}}$ & $5.6 \pm 1.5^{\mathrm{b}}$ \\
\hline D2 & $40.2 \pm 15.5^{\mathrm{a}}$ & $7.1 \pm 1.2^{\mathrm{a}}$ & $21.2 \pm 9.8^{\mathrm{b}}$ & $5.3 \pm 1.5^{\mathrm{a}}$ \\
\hline
\end{tabular}

$a, b, c$ Different letter superscripts in the same column indicate significant difference $(p<0.05)$. Digestive cells $(n=30)$; blue granule counts and diameters $(n=90)$.

Table 3: Digestive cell measurements, blue granule counts and diameters, and Feed Index values (average and standard deviation [SD]) in digestive gland samples from S.pugilis fed Diet 1 (D1) or Diet 2 (D2), and a wild conch (WC) control treatment.

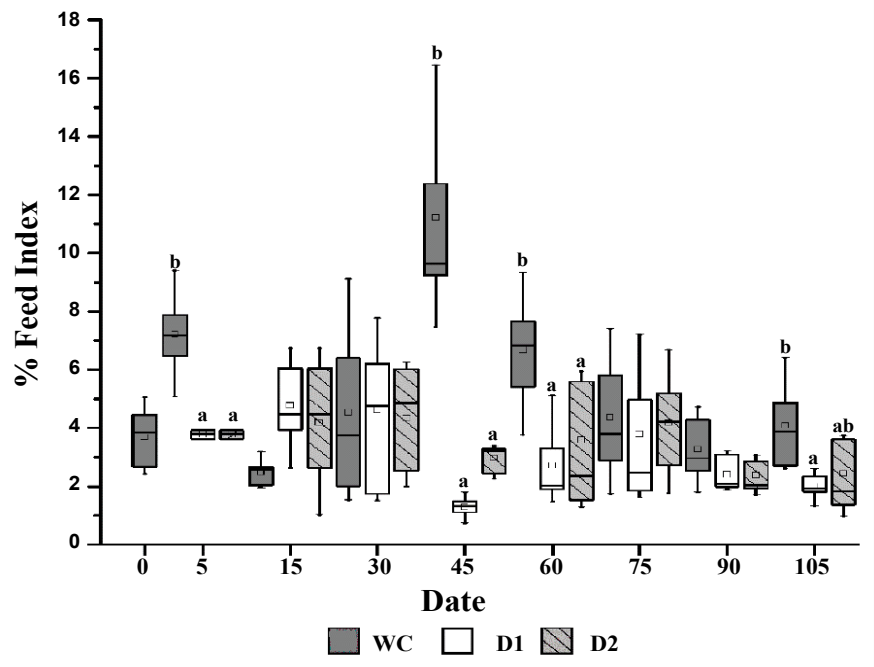

Figure 2: Box plots ( $\mathrm{n}=90$ in each plot) showing digestive gland feed index (Aldana and Frenkiel, 2012) values for wild Strombus pugilis and those fed Diet 1 or Diet 2 for 105 days. Significant differences in values between treatments were identified with the Kruskal-Wallis test between diets on sampling days $45(P=0.001), 60(P=0.01)$ and $105(P=0.03)$.

$\pm 37.3 \mu \mathrm{m}$, with a large, compact nucleus. No nucleolus was observed, and yolk granules measured $5.4 \pm 1.2 \mu \mathrm{m}$ (Figure 3C, Tables 4 and 5).

(d) Spawning: Connective tissue between ovigerous tubules was abundant, and tubule diameter decreased. No oocytes were observed in the tubules, and only yolk remnants from eggs expelled during spawning were present (Figure 3D).

The female gonad structures at different oogenesis stages demonstrated that tubule diameter and previtellogenic and vitellogenic oocyte size increased during oogenesis process. Tubule, oocyte and yolk granule diameters in the D1 treatment were larger than D2 and wild conch (Tables 4 and 5). The one-way ANOVA showed mean yolk granule diameter to differ $(\mathrm{P}<0.0001)$ between treatments.

\section{Males}

(a) Early spermatogenesis: Abundant connective tissue structures were observed between the sperm tubules, which measured $82.2 \pm 29.3$ $\mu \mathrm{m}$ in diameter (Figure 3E and Table 6).

(b) Mid spermatogenesis: Less connective tissue was present between the tubules, and tubule diameter increased to $151 \pm 38.1 \mu \mathrm{m}$ (Table 6). Numerous primary spermatocytes and some sperm packet formation were present. Large apyrenic sperm were frequent in the tubule lumen (Figure 3F).

(c) End spermatogenesis: This stage corresponds to testicle

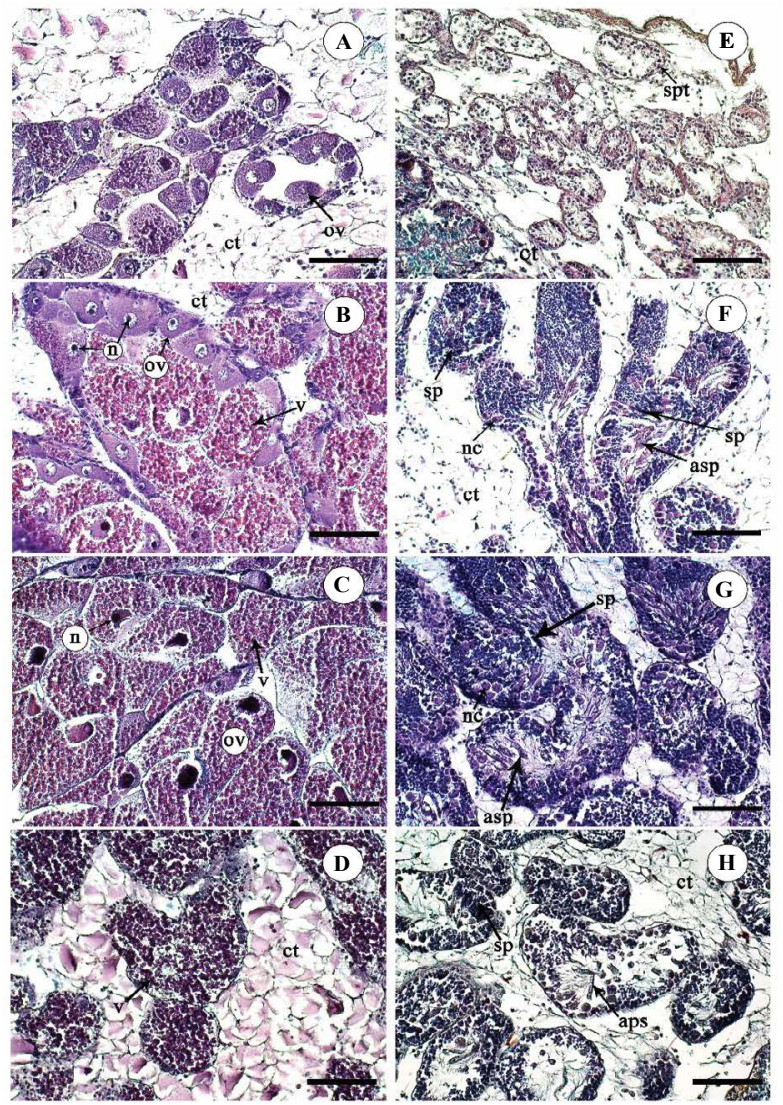

Figure 3: Micrographs (40x) of female and male Strombus pugilis gonads in different reproductive stages: $\mathrm{A}$ and $\mathrm{E}$ ) Early gametogenesis; $\mathrm{B}$ and $\mathrm{F}$ ) Mid gametogenesis; $C$ and $G$ ) End gametogenesis; and $D$ and $H$ ) Spawning/ spent. Images show connective tissue (ct); oocyte nucleus (n) and oocyte with and without yolk granules (ov) [for females]; and apyrenic spermatozoa (asp), connective tissue (ct), nursery cells (nc), spermatozoa (sp); and spermatogonia (spt) [for males]. Bar $=100 \mu \mathrm{m}$.

\begin{tabular}{|c|c|c|c|c|c|c|c|c|c|c|c|c|c|c|c|}
\hline & \multirow{2}{*}{\multicolumn{3}{|c|}{$\begin{array}{c}\text { Tubule Diameter } \\
\qquad(\mu \mathrm{m})\end{array}$}} & \multicolumn{6}{|c|}{ Previtellogenic Oocyte } & \multicolumn{6}{|c|}{ Vitellogenic Oocyte } \\
\hline & & & & \multicolumn{3}{|c|}{ Length $(\mu \mathrm{m})$} & \multicolumn{3}{|c|}{ Width $(\mu \mathrm{m})$} & \multicolumn{3}{|c|}{ Length $(\mu \mathrm{m})$} & \multicolumn{3}{|c|}{ Width $(\mu \mathrm{m})$} \\
\hline & WC & D1 & D2 & WC & D1 & D2 & WC & D1 & D2 & WC & D1 & D2 & WC & D1 & D2 \\
\hline Early & $\begin{array}{c}94.2 \pm \\
19^{a}\end{array}$ & $\begin{array}{c}101.5 \pm \\
25.5^{\mathrm{a}}\end{array}$ & $116 \pm 48^{a}$ & $\begin{array}{c}41.9 \pm \\
13.2^{\mathrm{a}}\end{array}$ & $\begin{array}{c}39.3 \pm \\
10.9^{\mathrm{a}}\end{array}$ & $\begin{array}{c}35.5 \pm \\
12.5^{\mathrm{a}}\end{array}$ & $\begin{array}{c}19.9 \pm \\
7.9^{\mathrm{a}}\end{array}$ & $\begin{array}{c}19.7 \pm \\
6.5^{\mathrm{a}}\end{array}$ & $\begin{array}{c}17.9 \pm \\
6.9^{\mathrm{a}}\end{array}$ & - & --- & -- & -- & --- & -- \\
\hline Mid & $\begin{array}{c}203.7 \pm \\
35.3^{\mathrm{a}}\end{array}$ & $\begin{array}{c}228.7 \pm \\
59.4^{\mathrm{a}}\end{array}$ & $\begin{array}{c}209.9 \pm \\
65.4^{\mathrm{a}}\end{array}$ & $\begin{array}{l}51.7 \pm \\
12.4^{\mathrm{ab}}\end{array}$ & $\begin{array}{l}54.5 \pm \\
13.6^{b}\end{array}$ & $48.9 \pm 11^{\mathrm{a}}$ & $27 \pm 7.7^{\mathrm{ab}}$ & $\begin{array}{c}28.6 \pm \\
8.7^{\mathrm{b}}\end{array}$ & $\begin{array}{c}24.8 \pm \\
6.3^{\mathrm{a}}\end{array}$ & $\begin{array}{c}108.8 \pm \\
28.2^{\mathrm{ab}}\end{array}$ & $\begin{array}{c}105.2 \pm \\
27.2^{\mathrm{c}}\end{array}$ & $\begin{array}{c}117.2 \pm \\
35.5^{\mathrm{b}}\end{array}$ & $\begin{array}{c}60.7 \pm \\
18.7^{\mathrm{a}}\end{array}$ & $\begin{array}{c}60.4 \pm \\
21.5^{\mathrm{a}}\end{array}$ & $\begin{array}{l}64.5 \pm \\
22.5^{\mathrm{a}}\end{array}$ \\
\hline End & $\begin{array}{l}213 \pm \\
37.3^{a}\end{array}$ & $\begin{array}{c}267.5 \pm \\
52.8^{\mathrm{b}}\end{array}$ & $\begin{array}{c}212.2 \pm \\
75^{a}\end{array}$ & $\begin{array}{c}46.8 \pm \\
10.6^{a}\end{array}$ & $\begin{array}{l}54.7^{ \pm} \\
16.5^{b}\end{array}$ & $\begin{array}{l}42.1^{ \pm} \\
10.1^{a}\end{array}$ & $\begin{array}{c}22.7 \pm \\
6.3^{\mathrm{b}}\end{array}$ & $\begin{array}{c}27.7 \pm \\
9.2^{\mathrm{c}}\end{array}$ & $\begin{array}{c}17.9 \pm \\
4.8^{\mathrm{a}}\end{array}$ & $\begin{array}{l}143 \pm \\
25.1^{\mathrm{b}}\end{array}$ & $\begin{array}{c}147.7 \pm \\
29.5^{b}\end{array}$ & $\begin{array}{c}132.9 \pm \\
42.7^{\mathrm{a}}\end{array}$ & $\begin{array}{c}75.2 \pm \\
17^{\mathrm{a}}\end{array}$ & $\begin{array}{l}82.0 \pm \\
20.5^{b}\end{array}$ & $\begin{array}{l}78.6 \pm \\
29.7^{\mathrm{ab}}\end{array}$ \\
\hline
\end{tabular}

$a, b, c$ Different letter superscripts in the same column indicate significant difference $(p<0.05)$. (--- = No data available)

Table 4: Female gonad structures during oogenesis stages (Early, Mid and End), including tubule diameter ( $n=30$ ), and previtellogenic oocyte (no yolk granules) and vitellogenic oocyte (yolk granules) length and width ( $n=150)$, in S. pugilis fed Diet 1 (D1) or Diet 2 (D2), and a wild conch (WC) control treatment. 


\begin{tabular}{|c|c|c|c|c|c|c|c|c|c|}
\hline \multirow[t]{3}{*}{ Oogenesis } & \multicolumn{9}{|c|}{ Yolk granule diameter $(\mu \mathrm{m})$} \\
\hline & \multicolumn{3}{|c|}{ WC } & \multicolumn{3}{|c|}{ D1 } & \multicolumn{3}{|c|}{ D2 } \\
\hline & Average \pm SD & Min & Max & Average \pm SD & Min & Max & Average \pm SD & Min & Max \\
\hline Early & $3.9 \pm 1.0^{\mathrm{a}}$ & 1.5 & 6.9 & --- & --- & --- & $3.4 \pm 1.2^{\mathrm{b}}$ & 1.6 & 7.1 \\
\hline Mid & $5.6 \pm 1.0^{a}$ & 2.6 & 8.4 & $5.1 \pm 1.3^{b}$ & 1.9 & 8.6 & $4.1 \pm 1^{c}$ & 1.9 & 6.7 \\
\hline End & $5.4 \pm 1.2^{\mathrm{a}}$ & 1.8 & 9.5 & $6.3 \pm 1.3^{b}$ & 2.47 & 9.7 & $5.5 \pm 1.3^{a}$ & 1.8 & 9.5 \\
\hline
\end{tabular}

Table 5: Yolk granule diameter ( $\mathrm{n}=100$; average and standard deviation) during oogenesis stages (Early, Mid and End) in S. pugilis fed Diet 1 (D1) or Diet 2 (D2), and in a wild conch (WC) control treatment. A one-way ANOVA identified differences in mean yolk granule diameter between diets $(P<0.0001)$

\begin{tabular}{|c|c|c|c|}
\hline \multirow{2}{*}{ Spermatogenesis Stage } & \multicolumn{2}{|c|}{ Tubule Diameter $(\boldsymbol{\mu m})$} \\
\cline { 2 - 4 } & WC & \multicolumn{1}{c|}{ D1 } \\
\hline Early & $88.2 \pm 29.3^{\mathrm{b}}$ & $69.2 \pm 17^{\mathrm{a}}$ \\
\hline Mid & $151 \pm 38.1^{\mathrm{a}}$ & $145 \pm 32.4^{\mathrm{a}}$ & $13.8 \pm 19.8^{\mathrm{b}}$ \\
\hline End & $157.5 \pm 25.4^{\mathrm{b}}$ & $163.6 \pm 28.5^{\mathrm{b}}$ \\
\hline a,b,c Different letter superscripts in the same column indicate significant difference $(\mathrm{p}<0.05)$. & $132.1 \pm 46.9^{\mathrm{a}}$ \\
\hline
\end{tabular}

Table 6: Male gonad tubule diameter (average and standard deviation) in different spermatogenesis stages (Early, Mid and End) in S. pugilis fed Diet 1 (D1) or Diet 2 (D2), and in a wild conch (WC) control treatment.

maturity. Minimal conjunctive tissue was present between the seminiferous tubules. The tubules contained a higher amount of eupyrenic sperm packages, whereas apyrenic sperm and feeder cells were observed (Figure $3 \mathrm{G}$ and Table 6).

(d) Spent: Very little connective tissue was present between the seminiferous tubules in this stage. No spermatocytes were observed, and spermatogonia were present in smaller numbers (Figure $3 \mathrm{H}$ ).

The tubules in the male gonads increased in size during spermatogenesis. Tubule diameter was similar between D1 and WC, but less so when compared to D2 (Table 6).

(e) Rest: The gonads were composed of connective tissue only or connective tissue with tubule remains. No differences were present between male and female structures.

\section{Reproductive cycle}

\section{(a) Females}

Reproductive cycle in the wild conch during the study period began with $100 \%$ of females in end oogenesis (maturity), followed by a spawning stage and then immediately thereafter the beginning of a new oogenesis stage (Figure 4A). Spawning peaks were observed at 15 days $(50 \%)$ and 75 days (34\%). The early oogenesis process in the wild conch was very fast and therefore almost imperceptible in the sampling dates. In the D1 treatment, the reproductive cycle began with a period of maturity (end oogenesis) from days 0 to 45 , followed by spawning peaks at day $60(75 \%)$ and day $90(100 \%)$ (Figure 4B). This one month period between spawning peaks was about half the time required (two months) in the wild conch. The overall reproductive cycle in D2 was similar to D1, although end oogenesis lasted from days 0 to 30 , and only minor spawning peaks (25\% at day $60 ; 50 \%$ at day 75$)$ were observed (Figure 4C).

\section{(b) Males}

In the wild conch reproductive cycle, $50 \%$ of males were in the mid-spermatogenesis stage and $50 \%$ in the spent stage (Figure 4D). The latter exhibited two peaks: one at day 15 (50\% to $100 \%)$ and a second at day $60(32 \%)$. Two peaks were also present in the spent stage in the D1 treatment, although these were shorter and less intense than in the wild conch: the first was at day 15 (67\%) and the second at day 90 (25\%) (Figure 4E). Early spermatogenesis was broad and intense. Two peaks in the spent stage in the D2 treatment were very similar to those in
D1, and the resting stage was long, from day 5 to day 75 (30\% to $50 \%)$ (Figure 4F).

The Kruskal-Wallis test identified no differences between treatments (D1, D2 and WC) in the median number of females and males in the different reproductive stages: early/mid gametogenesis (Figures $5 \mathrm{~A}$ and $5 \mathrm{E}$ ); end gametogenesis (Figures $5 \mathrm{~B}$ and $5 \mathrm{~F}$ ); spawning/spent stages (Figures 5C and 5G); and rest stage - females only (Figure 5D). The one exception was for the rest stage in males $(\mathrm{H}=4.69 ; \mathrm{p}<0.011$; Figure $5 \mathrm{H})$.

\section{Discussion and Conclusion}

The cultivation of fresh and saltwater fish, shellfish and algae is an important and growing source of food production [14]. It has also helped to improve the condition of harvestable stocks of some marine resources. Sustainable aquaculture of Strombidae species requires harvest of broodstock raised using appropriate diets. A study of the natural diet of $S$. gigas in the Bahamas using I3C to identify components showed the principal food source to be macroalgae, particularly Laurencia spp. and Batophora oerstedi [4]. In another study of the natural diet of $S$. gigas juveniles and adults on San Pedro Bank, Belize, a total of 22 items were identified in the stomach contents. The most diverse phylum was Rodophyta, followed by Cyanophyta and Protozoa [6].

In mollusks, energy reserves are stored in the muscle $[15,16]$ and the digestive gland [16-18]. Proteoglycan granules have been identified inside digestive cells [19]. Based on the amount of proteoglycan granules in the digestive gland structure of $S$. gigas, a feed index has been proposed to assess its nutritional status [12]. Under moderate stress, energy distribution in invertebrates maintains basal metabolism, but under total stress, the organism suppresses energy storage and reproductive functions $[20,21]$. The digestive gland was used as an energy storage indicator in the present study. Feed index values were best in the wild conch, followed by conch fed D1 and D2, which did not differ between them.

Formulated diets most commonly use fishmeal to supply proteins, fatty acids, minerals and vitamins, and to make feed palatable [22]. Fatty acid levels affect growth and gametogenesis in mollusks [23-25]. The fatty acids profile of $H$. floresii includes high values of palmitic acid (28.36\% to $64.67 \%)$, oleic acid (6.62\% to $13.92 \%)$, linoleic acid $(1.03 \%$ to $4.65 \%)$ and arachidonic acid (4n6, 1.2\% to 6.9\%) [26]. Addition of feeding stimulants can enhance feed intake. Alginate and carrageenan 


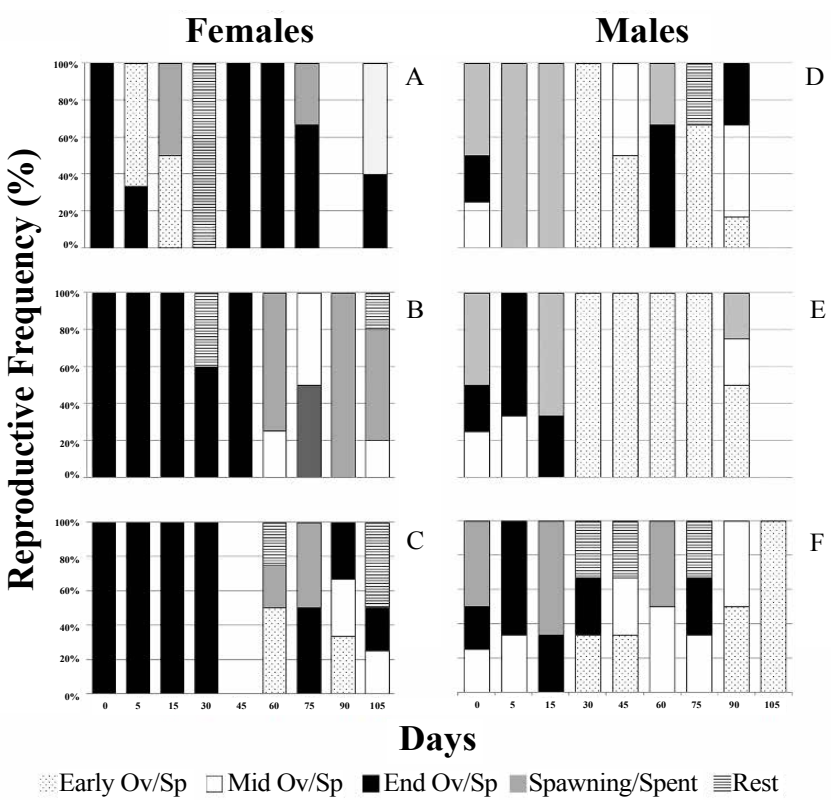

Figure 4: Reproductive stage frequency in female and male Strombus pugilis in the wild conch (2A and 2D), and in the Diet 1 (2B and 2E) and Diet 2 (2C and $2 \mathrm{~F}$ ) treatments during the 105-day experimental period.

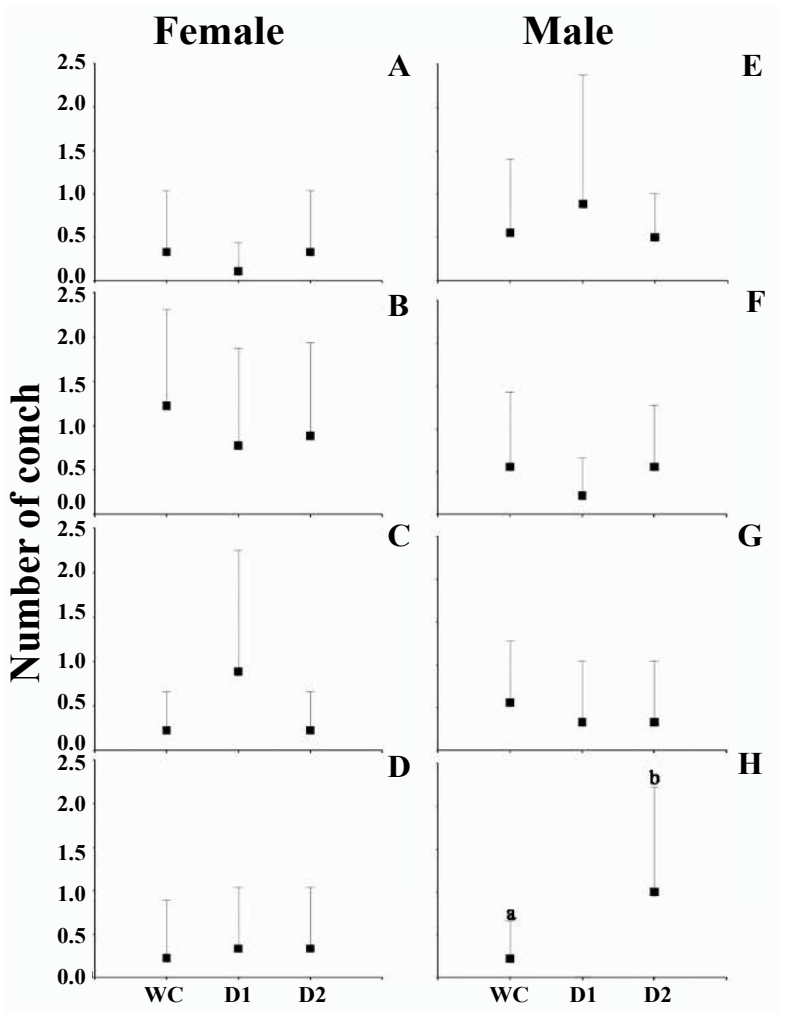

Diets

Figure 5: Median number of female and male Strombus pugilis in different reproductive stages (Early/Mid gametogenesis $3 \mathrm{~A}$ and $3 \mathrm{E}$; End gametogenesis $3 \mathrm{~B}$ and $3 \mathrm{~F}$; Spawning/spent $3 \mathrm{C}$ and $3 \mathrm{G}$; and Rest and $3 \mathrm{D}$ and $3 \mathrm{H}$ ) in the wild conch, Diet 1 and Diet 2 treatments. A Kruskal-Wallis test identified no significant differences in median numbers between treatments (Figures 3A-3D), except for males in the rest stage $(p<0.011)$. function as feeding stimulants in diets for abalone [25]. Carrageenans are compounds extracted from certain red seaweeds (Rhodophyceae), and are widely used as gelling agents and stabilizers in aqueous mixtures and emulsions [27]. Among the algae known to contain carrageenans is $H$. floresii $[8,28]$. These compounds are vital to retaining watersoluble nutrients in feed, and maintaining feed particle integrity once in the water. This benefits slow feeders, and is crucial to the success of any formulated diet [29]. Bromophenols identified in the alga Eisenia bicyclis were found to be a chemical defense against herbivore attack [30]. Total bromophenol content varies between algae species, and is known to be lower in $H$. floresii than in Ulva species [31].

Adding algae to mollusk diets has produced positive results. In a feeding experiment using red abalone $H$. rufescens, the highest growth was observed with Porphyra columbiana, followed by a mixture of $P$. columbiana with a formulated diet [32]. It was found that growth of juvenile $H$. rufescens was highest with the macroalgae diet and the high macroalgae supplementation diet (76.1\% macroalgae: $23.9 \%$ formulated feed) [33]. Supplementation of a formulated feed (catfish chow) with the alga Agardhiella sp. in juvenile S. gigas resulted in better growth $\left(0.23 \mathrm{~mm} . \mathrm{d}^{-1}\right)$ than the formulated feed alone $\left(0.11 \mathrm{~mm} \cdot \mathrm{d}^{-1}\right)$ [5].

Spirulina has also been used to optimize artificial diets for growth performance in mollusks. It is a rich source of protein $(70 \%$ dry weight), carotenoids (4000 $\mathrm{mg} / \mathrm{kg}$ ), omega-3 and omega-6 polyunsaturated fatty acids, gamma linolenic acid (GLA), sulfolipids, glycolipids, polysaccharides, vitamins (A, E and B) and minerals [34]. The effect of five protein-rich ingredients Spirulina, casein, fishmeal, soya oil and torula yeast were tested in diets for the abalone $H$. midae. Fish meal and Spirulina diets produced higher increases in length and specific growth rate compared to the diets containing soya oil, torula yeast, and casein alone [35]. When fed formulated diets containing a combination of Spirulina, fish meal and shrimp meal the abalone $H$. asinine exhibited better growth rates than those fed diets containing only vegetable source protein sources [36]. In a study in which juvenile $H$. iris were fed one of nine diets containing different protein sources (white and red fishmeal, blood meal, meat and bone meal, casein, soybean concentrate, wheat gluten, maize gluten, and Spirulina) the Spirulina diet produced growth similar to that of the fishmeal, soybean, and casein protein diets [37].

Feed availability and quality are critical factors in the induction of final maturation and spawning in invertebrate species [38]. In a study of the scallop Aequipecten irradians, nutrient reserves from ingested feed were apparently utilized during gonad growth and gametogenesis [17]. This process involved their transfer from the digestive gland to the gonad for use by the developing gametes for synthesis of various biochemical constituents. Testing of three diets (red seaweed Gracilariopsis bailinae only, formulated feed only, and a combination of G. bailinae and feed) in abalone $H$. asinina broodstock produced better reproductive performance (i.e. mean instantaneous fecundity and hatching rate percentages) with the combined seaweed/ feed and feed only treatments [23]. In other study, three diets (fresh green seaweed Ulva armoricana only, formulated feed only and a combination of $U$. armoricana at $20 \%$ and feed) were tested in the sea urchin Tripneustes gratilla, observing a higher gonad production with the combined seaweed/feed treatment [39].

The effects of diet on reproductive performance in conch species have only been addressed in two previous studies. The feasibility of a captive breeding program for S. gigas, S. raninus, S. alatus and S. costatus was tested using a prepared feed (36\% Mazuri Koi pellets, $16 \%$ Ulva sp.), and all four species were observed to produce egg 
masses [40]. Another study on the effects of two diets (koi chow and catfish chow) on reproductive output in S. alatus found no significant difference between the two treatments in the number of egg masses laid [41].

The relationship between dietary protein content and fecundity has received very little attention in mollusk aquaculture [42]. Fatty acids such as arachidonic acid are known to be precursors of the prostaglandins involved in reproductive processes in mollusks $[43,44]$. High arachidonic levels may not be required for muscle growth, but are clearly necessary for oogenesis and embryogenesis [45]. Carotenoids are known to modulate reproductive performance and enhance fertility in sea urchin (Loxechinus albus) [46]. In a similar manner, use of Spirulina as a carotenoid source in diets for the fish Pseudotropheus acei was found to increase egg laying rates compared to treatments using only fish meal [47].

The present results indicate that Diet 1 , containing the highest $H$. floresii and Spirulina levels, exhibited the best reproductive performance and the highest energy reserves in the digestive gland. These results suggest that the carrageenan present in $H$. floressi may function as a feeding stimulant, and the arachidonic acid may promote gonadal maturity. In addition, the carotenoids in the Spirulina very probably promoted gonadal ripening in the tested $S$. pugilis broodstock under laboratory conditions.

\section{Acknowledgements}

The authors wish to thank the Ichthyology Laboratory, CINVESTAV- IPN Merida, for access to their histology and digital photomicroscope facilities. Teresa Colás conducted the histological analyses. Halymenia floressi was provided by the Applied Phycology Laboratory, CINVESTAV- IPN Merida, and the Nutrition Laboratory, CINVESTAV- IPN Merida, ran the proximate analyses. English translation by John Lindsay-Edwards.

\section{Funding Sources}

The research reported here was financed by the project "El caracol rosa como indicador de cambio climático en el Caribe: acidificación oceánica y calentamiento" (Grant number CB-2012-01/181329).

\section{References}

1. Berg CJ (1975) Behavior and ecology of conch (Superfamily Strombacea) on a deep subtidal algal plain. Bull Mar Sci 25: 307-317.

2. FAO (2007) Regional workshop on the monitoring and management of queen conch, Strombus gigas. Kingston Jamaica FAO Fish Rep 832: 174.

3. Davis M (2000) Queen conch (Strombus gigas) culture techniques for research, stock enhancement and growout markets. In: Recent Advances in Marine Biotechnology

4. Stoner AW, Waite JM (1991) Trophic biology of Strombus gigas in nursery habitats: diets and food sources in seagrass meadows. J Molluscan Stud 57: 451-460.

5. Shawl A, Acosta-Salmon H, Davis M, Cape T, Richie MA (2008) Effect of protein origin in artificial diets on growth and survival of juvenile Queen Conch, Strombus gigas. Book of abstracts Aquac Am.

6. Serviere-Zaragosa E, Mazariegos-Villareal A, Aranda DA (2009) Preliminary observation of natural feed of Queen Conch Strombus gigas. Proc Gulf Carib Fish Inst 514-517.

7. Garr AL, Acosta S (2011) Growth and survival of juvenile Queen Conch Strombus gigas fed artificial diets containing varying levels of digestible protein and energy. North Am J Aquac 73: 34-41.

8. Freile-Pelegrín Y, Azamar JA, Robledo D (2011) Preliminary characterization of carrageenan from the red seaweed Halymenia floresii. J Aquat Food Prod Technol 20: 73-83

9. Jones DB, Munsey VE, Walker LE (1942) Report of committee on protein factors. J Assoc Off Anal Chem 25: 118-120.

10. Gabe M (1968) Techniques histologiques. Masson, Paris.
11. Gros O, Frenkiel L, Aranda DA (2009) Structural analysis of the digestive gland of the queen conch Strombus gigas Linnaeus, 1758 and its intracellular parasites. J Molluscan Stud 75: 59-68.

12. Aranda AD, Frenkiel L (2012) Digestive gland structure as a feed index fo juveniles of the queen conch, Strombus gigas, reared with formulated food. Aquac Nutr 18: 581-588

13. Sokal RR, Rohlf FJ (1995) Biometry: the principles and practice of statistics. In Biological Research, WH Freeman and Co., New York.

14. FAO (2010) World Review of Fisheries and Aquaculture.

15. Pazos AJ, Román G, Acosta CP, Sánchez JL, Abad M (1997) Lipid classes and fatty acid composition in the female gonad of Pecten maximus in relation to reproductive cycle and environmental variables. Comp Biochem Physiol B Biochem Mol Biol 117: 393-402.

16. Berthelin C, Kellner K, Mathieu M (2000) Storage metabolism in the Pacific oyster (Crassostrea gigas) in relation to summer mortalities and reproductive cycle (West Coast of France). Comp Biochem Physiol B Biochem Mol Biol 125 359-369.

17. Sastry AN, Blake NJ (1971) Regulation of gonad development in the bay scallop, Aequipecten irradians Lamarck. Biol Bull 140: 274-283.

18. De la Parra AN, Garcia O, San JF (2005) Seasonal variations on the biochemical composition and lipid classes of the gonadal and storage tissues of Crassostrea gigas (Thunberg, 1794) in relation to the gametogenic cycle. $J$ Shell Res 24: 457-467.

19. Volland JM, Gros O (2012) Cytochemical investigation of the digestive gland of two strombidae species (Strombus gigas and Strombus pugilis) in relation to the nutrition. Microsc Res Tech 75: 1353-1360.

20. Sokolova IM, Frederich M, Bagwe R, Lannig G, Sukhotin AA (2012) Energy homeostasis as an integrative tool for assessing limits of environmental stress tolerance in aquatic invertebrates. Mar Environ Res 79: 1-15.

21. Schneider JE (2004) Energy balance and reproduction. Physiol Behav 81: 289317.

22. Lovell RT (1992) Nutrition and feeding of channel catfish. Proc Aquac Nutr Worshop 1-8.

23. Bautista-Teruel MN, Millamena OM, Fermin AC (2001) Reproductive performance of hatchery-bred donkey's ear abalone, Haliotis asinina, Linne, fed natural and artificial diets. Aquac Res 32: 249-254.

24. Grubert MA, Dunstan GA, Ritar AJ (2004) Lipid and fatty acid composition of pre- and post-spawning blacklip (Haliotis rubra) and greenlip (Haliotis laevigata) abalone conditioned at two temperatures on a formulated feed. Aquaculture 242: $297-311$

25. Uki N, Kemuyama A, Watanabe T (1985) Development of semi purified test diets for abalone. Bull Jpn Sot Sci Fish 51: 1825-1833.

26. Polat S, Ozogul Y (2008) Biochemical composition of some red and brown macro algae from the Northeastern Mediterranean Sea. Int J Food Sci Nutr 59: 566-572.

27. Campo VL, Kawano DF, Silva Jr DB, Carvalho I (2009) Carrageenans: Biological properties, chemical modifications and structural analysis - A review. Carbohydr Polym 77: 167-180.

28. Rodrigues JAG, Vanderlei ESO, Quinderé ALG, Queiroz INL, Bessa ÉF, et al. (2011) Analysis of two drying methods on the yield and activity of sulfated polysaccharides extracted from Halymenia sp. (Rhodophyceae). Acta Sci Biol Sci 34: 5-11.

29. Fleming AE, Van Barneveld RJ, Hone PW (1996) The development of artificial diets for abalone: A review and future directions. Aquaculture 140: 5-53

30. Shibata T, Miyasaki T, Miyake H, Tanaka R, Kawaguchi S (2014) The influence of phlorotannins and bromophenols on the feeding behavior of marine herbivorous gastropod Turbo cornutus. Am J Plant Sci 05: 387-392.

31. Whitfield FB, Helidoniotis F, Shaw KJ, Svoronos D (1999) Distribution of bromophenols in species of marine algae from Eastern Australia. J Agric Food Chem 47: 2367-2373.

32. Hernández J, Uriarte I, Viana MT, Westermeier R, Farías A (2009) Growth performance of weaning red abalone (Haliotis rufescens) fed with Macrocystis pyrifera plantlets and Porphyra columbina compared with a formulated diet. Aquac Res 40: 1694-1702. 
Citation: Sánchez FC, Díaz ME, Morales IM, Aranda DA (2016) Formulated Feed for Strombus pugilis (Mollusca, Gastropoda) Allowed Effective Gonad Maturity. J Aquac Res Development 7: 453. doi: 10.4172/2155-9546.1000453

33. Kemp JOG, Britz PJ, Toledo Agüero PH (2015) The effect of macroalgal, formulated and combination diets on growth, survival and feed utilisation in the red abalone Haliotis rufescens. Aquaculture 448: 306-314.

34. Ghaeni M, Roomiani L, Masomozadeh Z (2014) Review for uses and therapeutic effects of spirulina, Spirulina platensis microalgae. J Adv Pure Appl Sci 4.

35. Britz PJ (1996) The suitability of selected protein sources for inclusion in formulated diets for South African abalone, Haliotis midae. Aquaculture 140: 63-73.

36. Bautista-Teruel MN, Fermin AC, Koshio SS (2003) Diet development and evaluation for juvenile abalone, Haliotis asinina: animal and plant protein sources. Aquaculture 219: 645-653.

37. Tung $\mathrm{CH}$, Alfaro AC (2012) Alternative protein sources in artificial diets for New Zealand's black-footed abalone, Haliotis iris, Martyn 1784, Juveniles. J World Aquac Soc 43: 1-29.

38. Soudant P, Marty Y, Moal J, Robert R, Quéré C, et al. (1996) Effect of food fatty acid and sterol quality on Pecten maximus gonad composition and reproduction process. Aquaculture 143: 361-378

39. Cyrus MD, Bolton JJ, Macey BM (2015) The role of the green seaweed Ulva as a dietary supplement for full life-cycle grow-out of Tripneustes gratilla. Aquaculture 446: 187-197.

40. Shawl A, Davis M (2004) Captive Breeding behavior of four Strombidae conch J Shellfish Res 23: 157-164.
41. Gillette P, Shawl A (2006) Effects of diet and sex ratio on the reproductive output of the Florida fighting conch, Strombus alatus. Proc Gulf Carib Fish Inst 57: 947-954.

2. Bilbao A, Tuset V, Viera M, Vicose GCD, Fernández-Palacios $\mathrm{H}$, et al. (2010) Reproduction, fecundity, and growth of abalone (Haliotis tuberculata coccinea, Reeve 1846) in the Canary Islands. J Shellfish Res 29: 959-967.

43. Nelson MM, Leighton DL, Phleger CF, Nichols PD (2002) Comparison of growth and lipid composition in the green abalone, Haliotis fulgens, provided specific macroalgal diets. Comp Biochem Physiol B Biochem Mol Biol 131: 695-712.

44. Bell JG, Sargent JR (2003) Arachidonic acid in aquaculture feeds: current status and future opportunities. Aquaculture 218: 491-499.

45. Daume S, Ryan S (2004) Fatty acid composition of eggs derived from conditioned and wild caught greenlip abalone broodstock (Haliotis laevigata). J Shell Res 23: 967-974.

46. Pérez AF, Malanga G, Puntarulo S (2011) Reproductive condition associated to changes in the lipid-soluble antioxidant capacity and damage to lipids in the sea urchins Loxechinus albus (Echinodermata echinoidea). Rev Mar Cost 3 : 183-194.

47. Güroy B, Şahin I, Mantoğlu S, Kayalı S (2012) Spirulina as a natural carotenoid source on growth, pigmentation and reproductive performance of yellow tail cichlid Pseudotropheus acei Aquac Int 20: 869-878. 